\title{
DNA Polymerase Beta
}

National Cancer Institute

\section{Source}

National Cancer Institute. DNA Polymerase Beta. NCI Thesaurus. Code C18023.

DNA polymerase beta (335 aa, $38 \mathrm{kDa}$ ) is encoded by the human POLB gene. This protein plays a role in both DNA replication and base excision repair. 